\title{
Glucose-6-Phosphate Dehydrogenase Deficiency and the Benefits of Early Screening
}

\author{
Julie Jensen DelFavero, RN, BSN \\ Amy J. Jnah, DNP, APRN, NNP-BC \\ Desi Newberry, DNP, APRN, NNP-BC
}

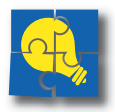

\section{Continuing Nursing} Education (CNE) Credit

The test questions are provided in this issue. The posttest and evaluation must be completed online. Details to complete the course are provided online at academyonline. org. Sign into your ANN account or register for a non-member account if you are not a member. A total of 1.6 contact hour(s) can be earned as CNE credit for reading this article, studying the content, and completing the online posttest and evaluation. To be successful, the learner must obtain a grade of at least 80 percent on the test. The test expires three (3) years from the publication date of this journal. Disclosures: The members of the activity planning committee and the test panel have no relevant financial interests or affiliations with any commercial interests related to the subjects discussed within this article. No commercial support or sponsorship was provided for this educational activity. Neither ANN nor ANCC endorses any commercial products discussed/displayed in conjunction with this educational activity.

The Academy of Neonatal Nursing is accredited with distinction as a provider of continuing nursing education by the American Nurses Credentialing Center's Commission on Accreditation. Provider, Academy of Neonatal Nursing, approved by the California Board of Registered Nursing, Provider \#CEP 6261; and Florida Board of Nursing, Provider \#FBN 3218, CE Broker \# 50-3066.

The purpose of this article is to discuss the state of the science regarding G6PD deficiency, increase provider awareness of this disease process, and reinforce the need for mandated G6PD deficiency screening mechanisms.

Julie Jensen DelFavero, Amy J. Jnah, and Desi Newberry have no conflicts of interest to declare.

Funding. The authors received no specific grant or financial support for the research, authorship, and/or publication of this article.

Accepted for publication

February 26, 2020

\begin{abstract}
Glucose-6-phosphate dehydrogenase (G6PD) deficiency, the most common enzymopathy worldwide, is an insufficient amount of the G6PD enzyme, which is vital to the protection of the erythrocyte. Deficient enzyme levels lead to oxidative damage, hemolysis, and resultant severe hyperbilirubinemia. If not promptly recognized and treated, G6PD deficiency can potentially lead to bilirubin-induced neurologic dysfunction, acute bilirubin encephalopathy, and kernicterus. Glucose-6-phosphate dehydrogenase deficiency is one of the three most common causes for pathologic hyperbilirubinemia. A change in migration patterns and intercultural marriages have created an increased incidence of G6PD deficiency in the United States. Currently, there is no universally mandated metabolic screening or clinical risk assessment tool for G6PD deficiency in the United States. Mandatory universal screening for G6PD deficiency, which includes surveillance and hospital-based risk assessment tools, can identify the at-risk infant and foster early identification, diagnosis, and treatment to eliminate neurotoxicity.
\end{abstract}

Keywords: acute bilirubin encephalopathy; G6PD; glucose-6-phosphate dehydrogenase deficiency; hyperbilirubinemia; kernicterus; metabolic; newborn screening

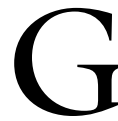

LUCOSE-6-PHOSPHATE DEHYDROGENASE (G6PD) deficiency most commonly involves a tenfold reduction in enzyme activity within the erythrocyte. The G6PD enzyme is important in the regulation of oxidative stress within the erythrocyte. Deficient enzyme levels destabilize the erythrocyte leading to oxidative damage and hemolysis. ${ }^{1-5}$ During the early postnatal period, an increased rate of hemolysis can give rise to severe hyperbilirubinemia. If unrecognized and untreated, bilirubin-induced neurologic dysfunction (BIND), acute bilirubin encephalopathy $(\mathrm{ABE})$, and kernicterus can develop during the initial hospitalization or in the timeframe between hospital discharge and the first outpatient pediatric visit.

Glucose-6-phosphate dehydrogenase deficiency is regarded as the most common enzymopathy and affects approximately five percent of the global population (Table 1). ${ }^{6-8} \mathrm{~A}$ change in migration patterns and intercultural marriages have created an increased prevalence of G6PD deficiency in the United States. ${ }^{9-11}$ Risk factors include ethnicity originating from malariaendemic areas such as the Mediterranean basin, Middle East, Asia, and Africa; male gender; and a family history of this $\mathrm{X}$-linked recessive disorder (Table 2). ${ }^{8,12-15}$ 
TABLE 1 Global Incidence of G6PD Deficiency ${ }^{16-38}$

\begin{tabular}{|c|c|}
\hline Regions/Countries & Percentage of G6PD Deficiency \\
\hline Africa & \\
\hline $\begin{array}{l}\text { Nigeria } \\
\text { Uganda } \\
\text { Sudan } \\
\text { Benin } \\
\text { Greece } \\
\text { Italy } \\
\text { Sardinia } \\
\text { India } \\
\text { Pakistan } \\
\text { South China }\end{array}$ & $\begin{array}{c}16.9 \\
14.5 \\
15.3 \\
23 \\
4.5 \\
3 \\
7.5-33 \\
27 \\
15 \\
4-20\end{array}$ \\
\hline $\begin{array}{c}\text { Southeast Asia } \\
\text { Cambodia } \\
\text { Laos } \\
\text { Myanmar } \\
\text { Thailand } \\
\text { Vietnam } \\
\text { Malaysia } \\
\text { Philippines } \\
\text { Indonesia }\end{array}$ & $\begin{array}{c}7-14.3 \\
3.1 \\
10.8 \\
3-18 \\
2-31 \\
3.1 \\
4.5-25.7 \\
6.2\end{array}$ \\
\hline $\begin{array}{l}\text { Middle East } \\
\text { Turkey } \\
\text { Syria } \\
\text { Cyprus } \\
\text { Lebanon } \\
\text { Iraq } \\
\text { Iran } \\
\text { Israel } \\
\text { Jordan } \\
\text { Gaza Strip } \\
\text { Egypt } \\
\text { Saudi Arabia } \\
\text { Kuwait } \\
\text { Yemen } \\
\text { Oman } \\
\text { Bahrain } \\
\text { United Arab Emirates }\end{array}$ & $\begin{array}{c}0.5-20 \\
30 \\
7-10 \\
3 \\
6.1 \\
11.6 \\
4.33 \\
10-15 \\
3.5 \\
5.9 \\
1-39.8 \\
5.5 \\
6.2 \\
2-29 \\
18 \\
11\end{array}$ \\
\hline
\end{tabular}

Abbreviation: G6PD = glucose-6-phosphate dehydrogenase.

TABLE 2 Familial Risk Factors for G6PD Deficiency ${ }^{1,6,8}$

\begin{tabular}{l}
\hline Family history \\
\hline Prolonged neonatal jaundice \\
\hline Recurrent jaundice \\
Anemia \\
Splenomegaly \\
Cholelithiasis \\
Favism
\end{tabular}

Abbreviation: G6PD = glucose-6-phosphate dehydrogenase.

While G6PD deficiency is a known protective mechanism against malaria (hence its prevalence in malaria-endemic areas), it is associated with significant neonatal morbidity because of hyperbilirubinemia-induced, severe, neurotoxic consequences. ${ }^{4}$

Currently, there is no universally mandated metabolic screening or clinical risk assessment tool for G6PD deficiency in the United States. ${ }^{8,11,39}$ As a result, G6PD-deficient infants may not be identified during their initial hospitalization and do not undergo appropriate screening for the development of severe hyperbilirubinemia. Affected infants, particularly those discharged home without a diagnosis of G6PD deficiency whose disease process is triggered by stressors such as infection, quickly develop severe hyperbilirubinemia, which could cause BIND, ABE, and kernicterus. ${ }^{8,11,12}$ It is imperative that clinicians independently appraise risk through a review of the maternal and family history and assess the progression of postnatal hyperbilirubinemia. Early hospital discharge is an additional risk factor because the infant may have minimal blood work ordered or fail to reach his peak total serum bilirubin (TsB) level when discharge occurs within 24-36 hours after birth. ${ }^{40}$

According to the National Quality Forum ${ }^{41}$ part of the Agency of Healthcare Research and Quality (AHRQ), and the American Academy of Pediatrics (AAP), ${ }^{42}$ hyperbilirubinemia that leads to kernicterus must be viewed as a "never event" and is "largely preventable". ${ }^{43}$ Failure to diagnose and treat infants with G6PD deficiency, regardless of the setting, puts infants at high risk for permanent brain damage and the clinician at risk for litigation and reprimand from state medical or nursing boards. ${ }^{40}$ The purpose of this article is to discuss the state of the science regarding G6PD deficiency, increase provider awareness of this disease process, and reinforce the need for a universally-mandated G6PD deficiency screening mechanism in the birth hospitalization because current systems appear inadequate and neurotoxic effects of hyperbilirubinemia still occur. ${ }^{40}$

\section{EPIDEMIOLOGY}

\section{Worldwide Distribution}

Glucose-6-phosphate dehydrogenase deficiency impacts infants born on every continent (Figure 1). ${ }^{4,44}$ Globally, 11 million G6PD-deficient infants are born each year. ${ }^{3,45,46}$ Approximately 7.5 percent of the worldwide population carry one to two genes for this disorder, making G6PD deficiency the fifth most common congenitally-acquired disorder. ${ }^{15,47}$ More than 33 percent of the global health burden imposed by hyperbilirubinemia is a result of G6PD deficiency. ${ }^{10}$

\section{G6PD Deficiency in the United States}

The incidence of G6PD deficiency is increasing in the United States, particularly among infants of East Asian and African American descent. ${ }^{8,11}$ The current U.S. prevalence is four to seven percent of live births, twice what was recorded in 1989. 3,7,46 The most significant ethnic risk factor of G6PD deficiency occurs in East Asians, as they have an incidence rate of 22 percent $(401,914$ males identified as East Asian only in 2017)..$^{15,48,49}$ Second to East Asian ethnicity are those of African American descent, with an incidence rate of $11-13$ percent in males and four percent 


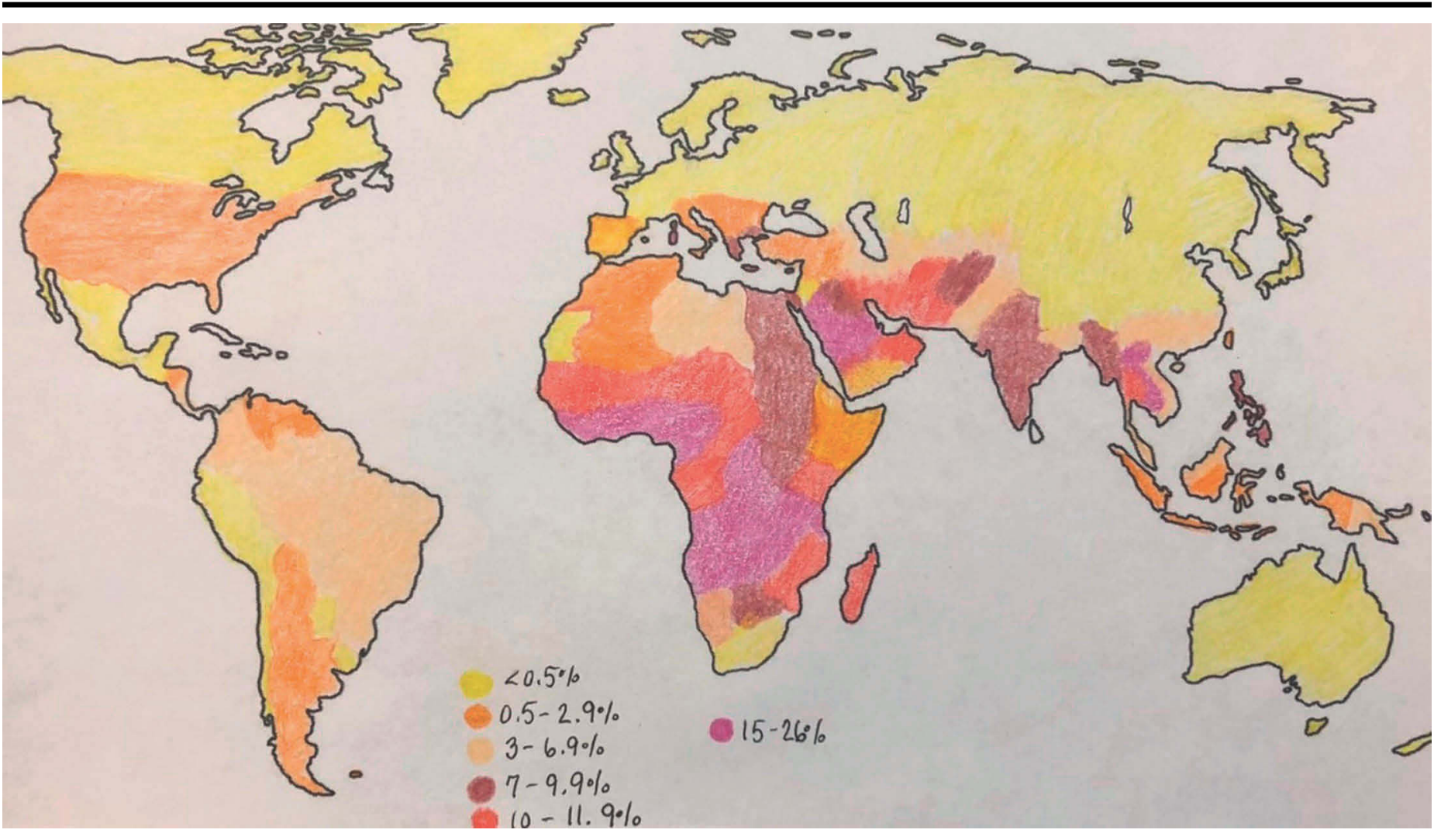

Note. Original artwork.

in females (2.1-2.5 million males and 864,296 females identified as African American only in 2017). ${ }^{1,15,40,49,50}$ These statistics are based on males and females who are identified as African American or East Asian only; therefore, there could be a higher prevalence because of intermarriage. Based on this data, it is likely that all neonatal clinicians will encounter East Asian or African American newborns with G6PD deficiency in their clinical practice. While some cities in the United States may report a low incidence of G6PD deficiency, that incidence is not zero, and therefore G6PD deficiency should be considered as part of a hyperbilirubinemia risk assessment and differential diagnosis in the face of rising bilirubin levels.

\section{GENETIC INFLUENCES}

The G6PD gene is mapped to the q-arm of the X chromosome $(\mathrm{Xq} 28)$ and is an $\mathrm{X}$-linked recessive disorder. ${ }^{13,34}$ Therefore, males comprise 90 percent of the affected individuals. ${ }^{51}$ The enzymopathy results from genetic mutations in the G6PD gene and the impact mostly affects erythrocytes. ${ }^{4}$

Males and females have different genotypes for G6PD deficiency because of its X-linked heritability (Figure 2). ${ }^{4}$ Male genotypes are hemizygous normal and hemizygous G6PD deficient. ${ }^{4}$ Female genotypes include homozygous normal, homozygous deficient, and heterozygous, which are genetic mosaics because of inactivation of the recessive X-chromosome. ${ }^{4,34,52}$ Genetic mosaics have 50 percent of their cells G6PD deficient and the remaining 50 percent normal in random inactivation, with the G6PD-deficient cells in female genetic mosaics as vulnerable to hemolysis as their G6PD-deficient male counterparts. ${ }^{39,53-55}$ Nonrandom inactivation also occurs, which produces three heterozygous female phenotypes: ten percent with normal G6PD enzyme activity, 80 percent with intermediate, and ten percent with low. ${ }^{56,57}$ Consequently, because of $\mathrm{X}$-linked inactivation, most affected females present with less severe symptoms of G6PD deficiency. The severity of symptoms is contingent on the extent of $\mathrm{X}$-chromosome inactivation. Rare cases have been reported of G6PDdeficient females who present with extreme hemolysis comparable to affected males. ${ }^{4,53}$

The World Health Organization (WHO) categorized G6PD deficiency variants into five classes, according to the level of enzyme deficiency, to forecast the severity of hemolysis in G6PDdeficient individuals (Table 3). ${ }^{13,39}$ Approximately 186 G6PD deficiency gene variants have been detected, each with variable clinical severity and ethnic prevalence; however, more than one variant can be present within a population or country. ${ }^{8,34}$ For example, an estimated 90 percent of G6PD deficiency in the 


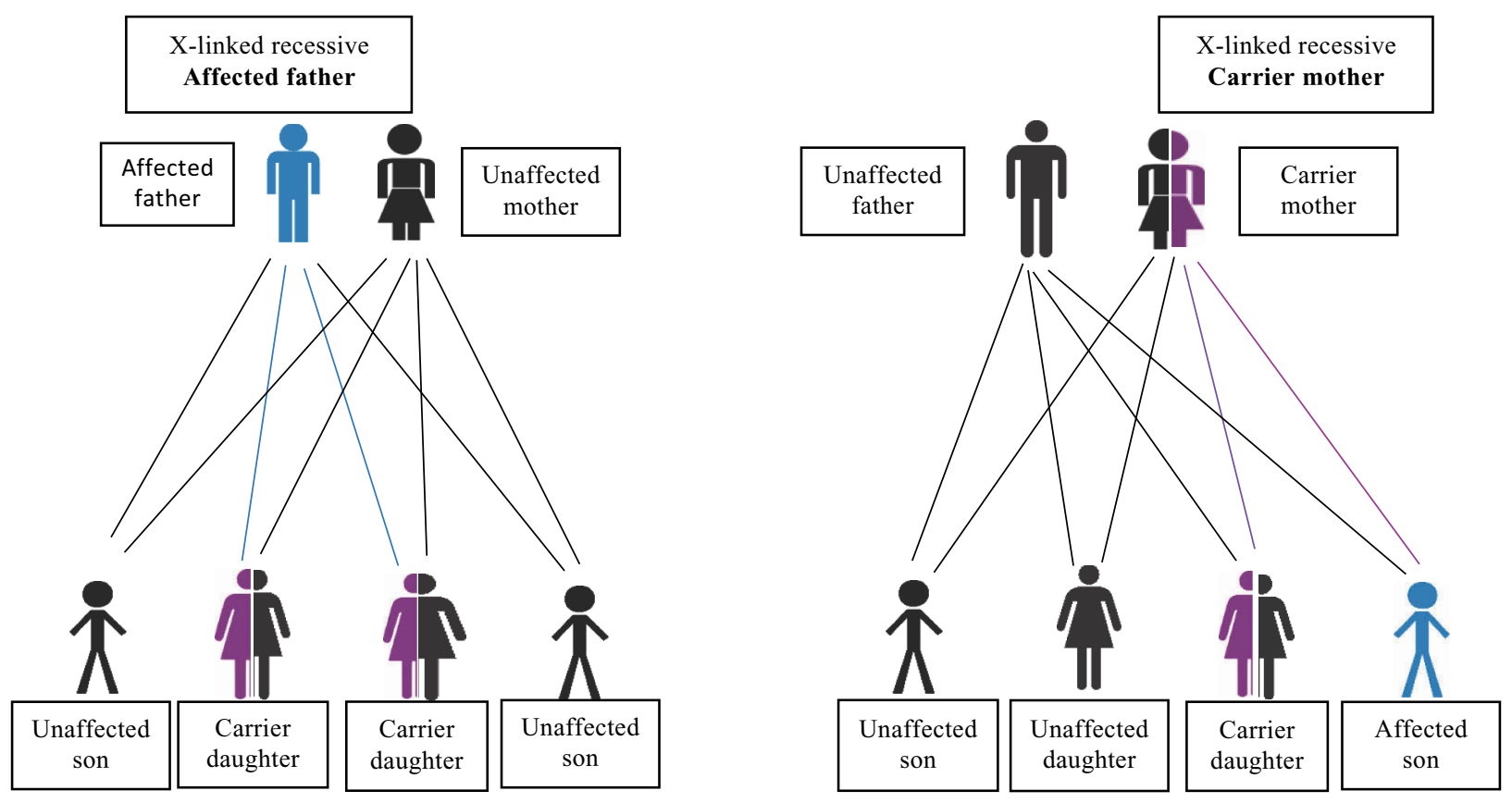

TABLE 3 The WHO Classification of G6PD Deficiency ${ }^{2,3,13}$

\begin{tabular}{ccc}
\hline G6PD Mutations & Level (Percentage) of Enzyme Activity & Health Outcome \\
\hline Class I & $<10$ & Severe-chronic hemolytic anemia \\
Class II & $<10$ & Severe-severe periodic hemolytic anemia \\
Class III & $10-60$ & Mild-stressor-induced hemolytic anemia \\
Class IV & $60-150$ & Asymptomatic \\
Class V & $>100$ & Asymptomatic \\
\hline
\end{tabular}

Abbreviations: G6PD = glucose-6-phosphate dehydrogenase; WHO = World Health Organization.

United States is caused by four gene variants. ${ }^{8}$ African $A$-, a class III variant, originated from Africa and is the most common variant in the United States that affects African Americans. ${ }^{8}$ A class III variant reduces enzyme activity by $40-100$ percent, which can cause significant hemolysis. ${ }^{8,59}$ There are only a few de novo mutations reported in the literature..$^{14,60-62}$

\section{PATHOGENESIS}

The primary role of the G6PD enzyme is to provide antioxidant defense for the erythrocyte. ${ }^{13}$ Normally, the G6PD enzyme is present in every cell and its function is to yield reduced nicotinamide adenine dinucleotide phosphate (NADPH), which is vital for many biologic functions including erythrocyte protection against oxidation and hemolysis. ${ }^{4}$ Initially, G6PD catalyzes the first stage of the pentose phosphate pathway (PPP) in glucose metabolism, which coincides with the reduction of nicotinamide adenine dinucleotide phosphate (NADP+) to NADPH. ${ }^{1,53} \mathrm{NADPH}$ then catalyzes glutathione disulfide to its reduced form, glutathione, an essential antioxidant highly concentrated in the erythrocyte. ${ }^{39}$
FIGURE 3 Role of G6PD enzyme $1,4,6,11,13,15,39,53,63$

\begin{tabular}{|c|c|c|c|c|c|c|c|c|}
\hline G6PD enzyme & $\Rightarrow$ & $\begin{array}{l}\text { Catalyzes } \\
\text { first stage in } \\
\text { glucose } \\
\text { metabolism }\end{array}$ & $\Rightarrow$ & $\begin{array}{l}\text { Reduction of } \\
\text { NADP to } \\
\text { NADPH }\end{array}$ & $\Rightarrow$ & $\begin{array}{c}\text { NADPH } \\
\text { catalyzes } \\
\text { glutathione } \\
\text { disulfate to } \\
\text { glutathione }\end{array}$ & $\Rightarrow$ & $\begin{array}{c}\text { Hemoglobin } \\
\text { shielded from } \\
\text { oxidation and } \\
\text { hemolysis }\end{array}$ \\
\hline
\end{tabular}

Abbreviations: G6PD = glucose-6-phosphate dehydrogenase; $\mathrm{NADPH}=$ nicotinamide adenine dinucleotide phosphate.

Lastly, glutathione shields the sulfhydryl groups of hemoglobin from oxidation, which would otherwise damage the erythrocyte (Figure 3). ${ }^{13}$

\section{Enzymopathy of the RBC in G6PD Deficiency}

A reduction in G6PD enzyme activity causes a malfunction in the PPP, which is the only origination of NADPH; therefore, NADPH production is decreased, which leads to depleted levels of glutathione. ${ }^{1,11,39}$ This causes the oxidation of the hemoglobin sulfhydryl groups and compromises the integrity of the erythrocyte membrane. ${ }^{13}$ This oxidative stress is the proximate cause for hemolysis and apoptosis of the erythrocyte..$^{1,13}$ 
Hemolysis of red blood cells (RBCs) releases bilirubin into the bloodstream, leading to an increased bilirubin load accumulating as the erythrocyte is removed by macrophages, the liver, and the spleen. This gives rise to concurrent hemolytic anemia and probable severe hyperbilirubinemia (Figure 4). ${ }^{6,15,63}$

\section{Neurotoxic Consequences}

Untreated, G6PD deficiency resulting in hemolysis may induce BIND, ABE, and kernicterus (Table 4). ${ }^{8,40}$ Serum total bilirubin (unconjugated [indirect] and conjugated [direct]) levels of $>25 \mathrm{mg} / \mathrm{dL}(427.6 \mu \mathrm{mol} / \mathrm{L})$ by 96 hours of age, which are typically higher than the diffusion threshold, can cause bilirubin to cross the blood-brain barrier and damage the basal ganglia and brainstem. ${ }^{3,40}$ Studies indicate that G6PD-deficient infants have a greater probability of developing kernicterus and G6PD deficiency is a significant risk factor for mortality and morbidity resulting from kernicterus. ${ }^{3,64}$

\section{RISK ASSESSMENT AND CLINICAL CORRELATION}

Prompt evaluation of the infant risk factors for severe hyperbilirubinemia is critical in avoiding devastating and permanent injury (Figure 5).,6,69 Risk factors include a TsB or transcutaneous bilirubin $(\mathrm{TcB})$ in the intermediate

FIGURE 4 Enzymopathy: G6PD deficiency 1,4,6,11,13,15,39,53,63

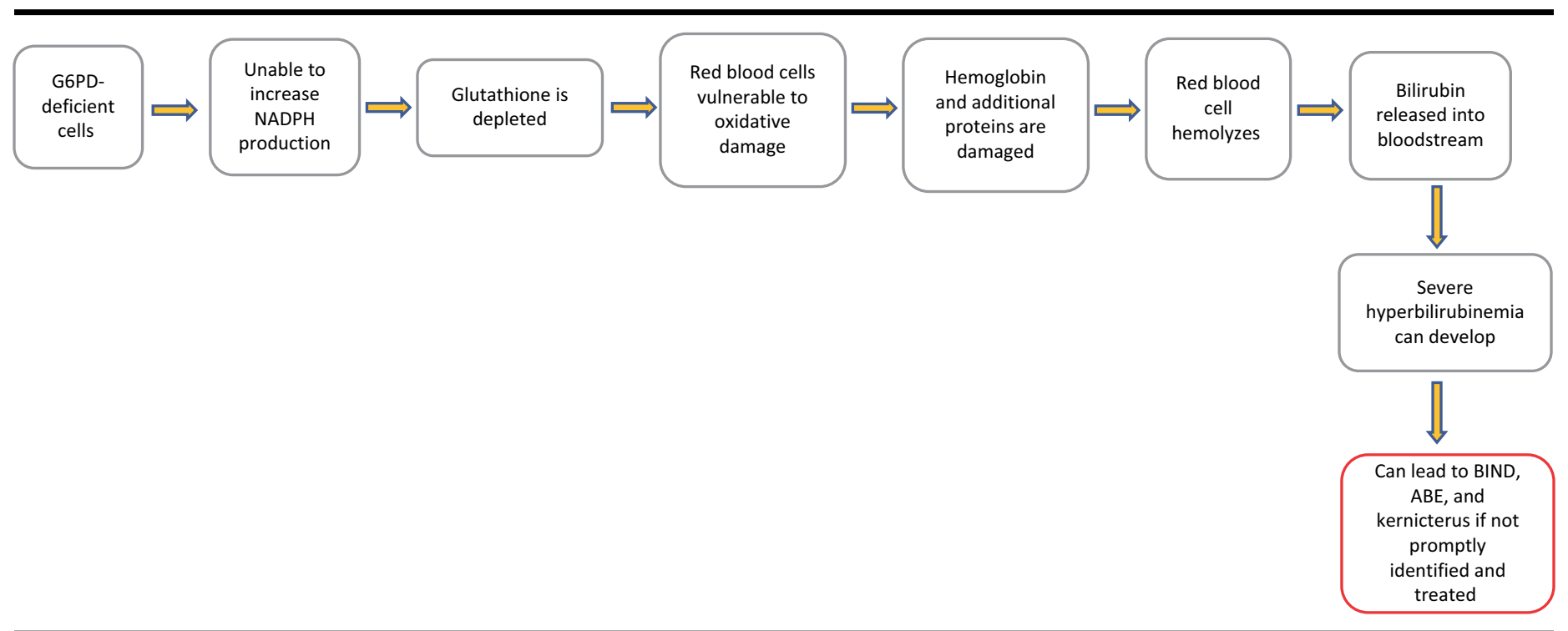

Abbreviations: $\mathrm{ABE}=$ acute bilirubin encephalopathy; BIND = bilirubin-induced neurologic dysfunction; G6PD = glucose-6-phosphate dehydrogenase; $\mathrm{NADPH}=$ nicotinamide adenine dinucleotide phosphate.

TABLE 4 Neurotoxic Consequences of G6PD Deficiency $3,8,40,42,65-68$

\begin{tabular}{|c|c|c|c|}
\hline \multicolumn{4}{|c|}{ Conditions } \\
\hline & BIND & ABE & Kernicterus \\
\hline Severity & $\begin{array}{l}\text { Least severe } \\
\text { neurodevelopmental } \\
\text { disabilities }\end{array}$ & $\begin{array}{l}\text { Severity dependent upon stage } \\
\text { Severity is progressive }\end{array}$ & $\begin{array}{l}\text { Irreversible } \\
\text { Most severe neurodevelopmental } \\
\text { disabilities }\end{array}$ \\
\hline \multirow[t]{3}{*}{$\begin{array}{l}\text { Clinical } \\
\text { Manifestations }\end{array}$} & $\begin{array}{l}\text { Lower TsB levels } \\
\text { Neonatal lethargy } \\
\text { Unanticipated apneas }\end{array}$ & Mild Stage: hypotonia, lethargy, and poor feeding & $\begin{array}{l}\text { Chronic manifestations of } A B E \\
\text { Evident in first year of life }\end{array}$ \\
\hline & & $\begin{array}{l}\text { Intermediate Stage (greater risk for permanent damage): } \\
\text { hypertonia, retrocollis, opisthotonos, high-pitched or } \\
\text { shrill cry, apnea }\end{array}$ & \\
\hline & & $\begin{array}{l}\text { Advanced Stage (most likely irreversible): } \\
\text { fever, apnea, seizures, decreased or absent feeding, deep } \\
\text { stupor, and severe retrocollis, opisthotonos, death }\end{array}$ & \\
\hline $\begin{array}{l}\text { Long-Term } \\
\text { Consequences }\end{array}$ & $\begin{array}{l}\text { Deafness, visual motor } \\
\text { disturbances, flat affect, } \\
\text { delay in smiling }\end{array}$ & $\begin{array}{l}\text { Must perform emergent exchange transfusion for } \\
\text { Intermediate and Advanced Stages } \\
\text { Reversible if detected promptly and treated emergently by } \\
\text { exchange transfusion in Mild and Intermediate Stages }\end{array}$ & $\begin{array}{l}\text { Athetoid cerebral palsy, permanent } \\
\text { movement difficulties, hearing loss, } \\
\text { upward gaze paralysis, tooth enamel } \\
\text { dysplasia, intellectual handicaps }\end{array}$ \\
\hline
\end{tabular}

Abbreviations: $\mathrm{ABE}$ = acute bilirubin encephalopathy; BIND = bilirubin-induced neurologic dysfunction; G6PD = glucose-6-phosphate dehydrogenase; $\mathrm{TsB}=$ total serum bilirubin. 


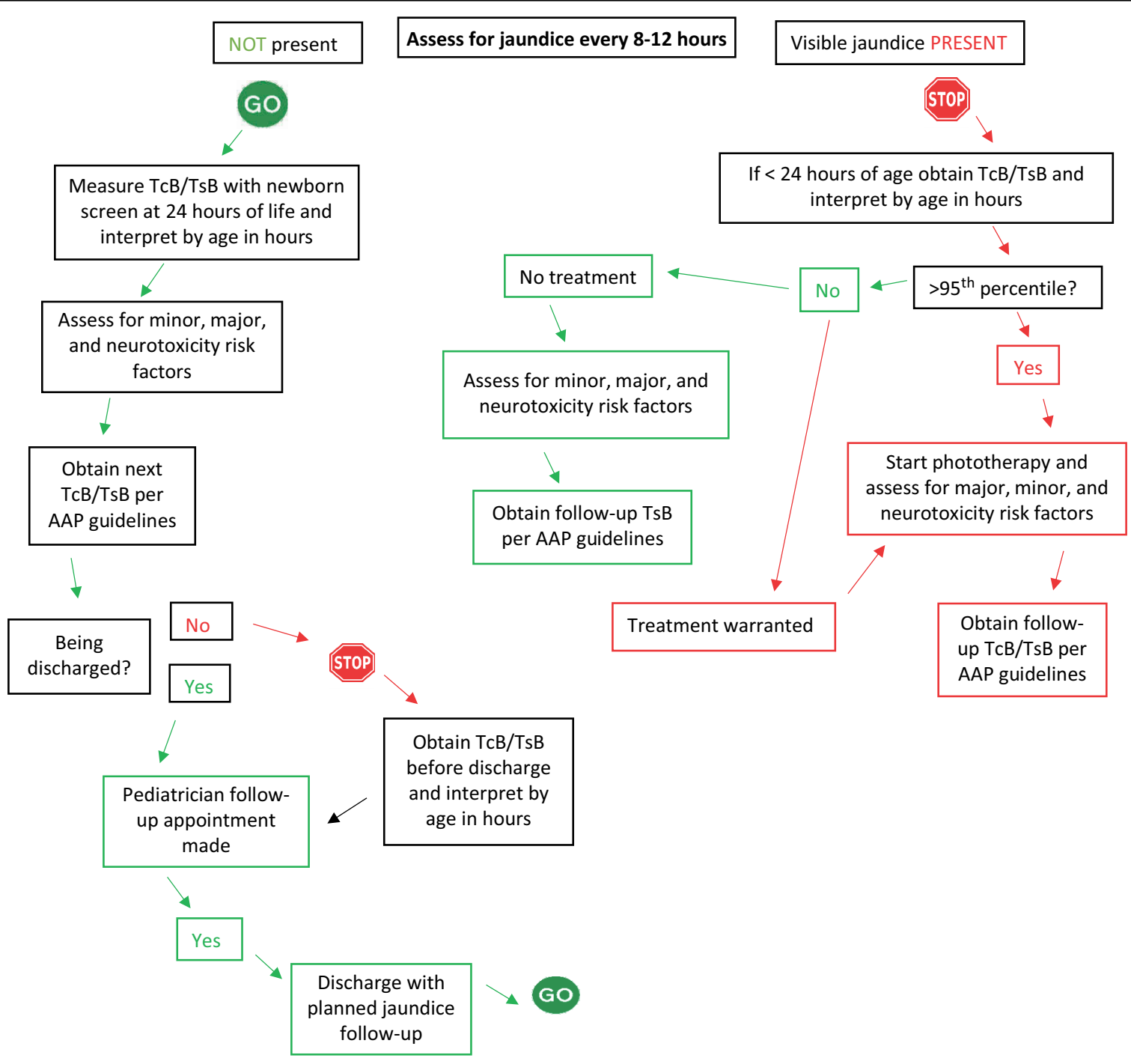

Abbreviations: $\mathrm{AAP}=$ American Academy of Pediatrics; $\mathrm{TcB}=$ transcutaneous bilirubin; $\mathrm{Ts} \mathrm{B}=$ total serum bilirubin.

TABLE 5 The Risk of Hyperbilirubinemia that Aligns with G6PD Deficiency ${ }^{42}$

\begin{tabular}{ll}
\hline Major Risk Factors & Minor Risk Factors \\
\hline TsB or TcB in high-risk zone & TsB or TcB in high-intermediate risk zone \\
\hline Visible jaundice in the first 24 hours & $37-38$ weeks' gestation \\
\hline ABO incompatibility with positive DAT or known hemolytic disease & Visible jaundice before discharge \\
\hline $35-36$ weeks' gestational age & Previous sibling with jaundice \\
\hline Previous sibling received phototherapy & Macrosomic infant of a diabetic mother \\
\hline Cephalohematoma or significant bruising & Maternal age $>25$ years \\
\hline Exclusive breastfeeding & Male gender \\
\hline East Asian race & \\
\hline
\end{tabular}

Abbreviations: DAT = direct antiglobulin test; G6PD = glucose-6-phosphate dehydrogenase; TcB = transcutaneous bilirubin; TsB = total serum bilirubin.

or high-risk zone, East Asian race, male gender, exclusive breastfeeding, and a family history of a sibling requiring phototherapy (Table 5$).{ }^{42}$
Rapidly rising bilirubin levels are a hallmark manifestation of G6PD deficiency. Serum total bilirubin levels can elevate by $10-15 \mathrm{mg} / \mathrm{dL}(171.04-256.56 \mu \mathrm{mol} / \mathrm{L})$ in only a few 
hours. ${ }^{8,63}$ Other noteworthy manifestations that may present just prior to or during the development of severe hyperbilirubinemia include feeding difficulties, fatigue, fussiness, irritability, and opisthotonos. Jaundice that progresses to the abdomen and extremities is associated with evolving hyperbilirubinemia; however, it is not a reliable indicator of rate of rise or severity of hyperbilirubinemia (Figure 6). ${ }^{70}$

\section{Evaluation of Risk Factors and Bilirubin Results}

All newborns should be frequently evaluated for hyperbilirubinemia during the birth hospitalization, regardless of the presence or absence of risk. ${ }^{42}$ Unfortunately, risk assessment is often exclusive to the interpretation of laboratory results and not the holistic assessment of family history, ethnicity, and presence of other risks clearly articulated in the Bhutani nomogram for infants $<35$ weeks' gestation ${ }^{42}$ and the

FIGURE 6 Manifestations of hyperbilirubinemia ${ }^{70,71}$

\section{Severe Manifestations}

\section{Convulsions}

Opisthotonos

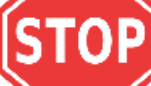

Respiratory distress

Fever

Moderate Manifestations

Hypotonia

Sucking impairment

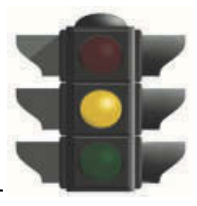

Motor abnormalities

Irritability

Mild Manifestations

Poor feeding

Lethargy
Maisels and colleagues ${ }^{72}$ guidelines for infants $<35$ weeks' gestational age.

Initially, clinicians should identify the gestational age of the infant. This will guide them toward use of the $\mathrm{AAP}^{42}$ nomogram for term infants or Maisels and colleagues ${ }^{72}$ guidelines for infants $<35$ weeks' gestation. Clinicians should then review the maternal medical record and identify medical or ethnic/cultural risk factors and discuss the family health history, including the history of siblings, with the birth parents or guardians. This permits clinicians to assign a neurotoxicity risk category.

Next, interval bilirubin assessments should commence after birth; an early onset of testing with increased frequency is indicated for infants at risk for hemolytic disease and severe hyperbilirubinemia. For infants $<35$ weeks' gestational age, the $\mathrm{TcB}$ or TsB results should be interpreted according to the diagnostic guidance offered by the $\mathrm{AAP}^{42}$ or Maisels and colleagues. ${ }^{72}$ Bilirubin results should be plotted on the Bhutani nomogram for infants $<35$ weeks' gestation to determine the phototherapy threshold, hour-specific risk severity, and the recommended interval for repeat testing. ${ }^{42,73}$ Repeat testing is warranted for high-risk levels within 6-12 hours, high-intermediate levels within 24-48 hours, and low-intermediate levels within 48 hours. ${ }^{42}$

For infants $<35$ weeks' gestational age, TcB or TsB results should be interpreted according to the diagnostic guidance offered by Maisels and colleagues. ${ }^{72}$ In addition, the PremieRecs tool (https://pbr.stanfordchildrens.org) can be used to aid clinical management and laboratory monitoring of hyperbilirubinemia among infants $<35$ weeks' gestation and who are $>48$ hours of age.

Transcutaneous bilirubin screening is a pain-free and cost-effective clinical monitoring tool that offers immediate results; its use as an exclusive diagnostic tool remains subject to debate. ${ }^{40}$ Transcutaneous bilirubin measurements demonstrate good agreement with TsB measurements among premature and term infants and afford clinicians a unique ability to trend bilirubin rate of rise without exposing the infant to repetitive, painful phlebotomy testing. ${ }^{40}$

\section{DIAGNOSTIC STRATEGIES FOR G6PD DEFICIENCY}

The diagnosis of G6PD deficiency can be made through several approaches, including a complete blood count (CBC) and peripheral blood smear, qualitative and quantitative assays measuring G6PD enzyme activity, ${ }^{1}$ or the gold standard for diagnosing G6PD deficiency which is genetic molecular testing via the polymerase chain reaction (PCR). ${ }^{1,13,34}$

\section{Hematologic Indicators for G6PD Deficiency}

Analysis of a CBC and peripheral blood smear as well as an examination of the RBC indices can differentiate between G6PD deficiency and hereditary spherocytosis (HS), the third most common nonhemolytic cause for hyperbilirubinemia. ${ }^{13,74}$ The mean corpuscular hemoglobin concentration 
(MCHC) divided by the mean corpuscular volume (MCV) provides the "Neonatal HS Index" and can correlate the probability of disease, with a result of $>0.36$ indicating a high probability of HS. ${ }^{74,75}$ The peripheral blood smear in HS demonstrates spherocytes, while findings in G6PD deficiency include polychromasia, poikilocytes, hemighosts, bite or blister cells, or Heinz bodies. ${ }^{6,13,76-78}$ Additionally, microparticles, which are cast off from a cell during oxidative stress and apoptosis, are elevated at levels of $865-2,532 / \mu \mathrm{L}$ compared to normal levels of $235-575 / \mu \mathrm{L} .{ }^{79}$

Additional hematologic findings can further narrow the differential diagnosis of G6PD deficiency. ${ }^{77}$ Providers must be aware of G6PD deficiency in the differential diagnosis of nonimmune hemolytic anemia because of its increasing prevalence (Table 6). ${ }^{39}$ Findings consistent with G6PD deficiency include low hemoglobin levels (reference range of 13.4-18.5 g/dL [134-185 g/L] for birth to two weeks of life), elevated lactic dehydrogenase (upper normal limit is in the range of 500-700 U/L), absent haptoglobin, and reticulocytosis of 20 percent or greater. ${ }^{13,39,76,80,81}$ Glucose-6phosphate dehydrogenase deficiency screening in an infant demonstrating reticulocytosis, active hemolysis, or post-acute hemolysis could potentially lead to a false negative result. ${ }^{11,42}$ In these states, the oldest RBCs with the lowest G6PD enzyme levels are eradicated and replaced with reticulocytes that have up to a fivefold amount of the G6PD enzyme, causing a temporary increase in the G6PD enzyme level. ${ }^{6,54}$ Therefore, these infants should be tested again at three months of age. ${ }^{42}$

\section{G6PD Deficiency Enzyme Assays}

Another diagnostic strategy involves a qualitative or quantitative analysis of the generation of NADPH through NADP+ reduction which is commensurate to the level of G6PD enzyme activity. ${ }^{1,83}$ Quantitative assays measure NADPH production through spectrophotometric analysis and this is considered the superior G6PD enzyme test because of its ability to detect the full spectrum of deficiency. ${ }^{11,54}$ The normal G6PD enzyme activity range is 7-10 U/g of hemoglobin. In G6PD deficiency, enzyme activity will be less than 20 percent

TABLE 6 Differential Diagnosis of G6PD Deficiency ${ }^{6,82}$

\begin{tabular}{ll}
\hline Disease or Disorder & Classification \\
\hline G6PD deficiency & Erythrocyte enzyme defect \\
\hline Pyruvate kinase deficiency & Erythrocyte enzyme defect \\
\hline Gilbert's syndrome & Inherited gene mutation \\
\hline Hereditary spherocytosis & Erythrocyte membrane defect \\
\hline Hemolytic disease of the newborn & Newborn blood disorder \\
\hline Sickle-cell disease & Hereditary hemoglobinopathy \\
\hline Alpha-thalassemia & Hereditary hemoglobinopathy \\
\hline Gamma-thalassemia & Hereditary hemoglobinopathy \\
\hline Elliptocytosis & Erythrocyte membrane defects \\
\hline Pyknocytosis & Erythrocyte membrane defects \\
\hline
\end{tabular}

Abbreviation: G6PD = glucose-6-phosphate dehydrogenase. of normal or below $2 \mathrm{U} / \mathrm{g}$ of hemoglobin., ${ }^{1,54}$ Turnaround time for quantitative test results can be 24 hours; timing for results may differ by institution. ${ }^{1}$ A quantitative assay can detect individuals with G6PD-deficient levels that are above the cutoff for deficiency values in a qualitative assay, therefore making the quantitative assay more sensitive. ${ }^{83}$

The WHO recommends the fluorescent spot test (FST), a qualitative enzyme assay, which visually discerns the production of NADPH under ultraviolet light. ${ }^{1,11}$ A positive test occurs if the blood spot does not fluoresce under ultraviolet light. ${ }^{84}$ Advantages of the FST are that it can be conducted in low-resource settings, the test is inexpensive, and test results are rapid; however, this test only detects severe deficiencies and consequently some G6PD-deficient individuals are missed. ${ }^{1,34,83}$ Therefore, in cases involving a suspected G6PDdeficient neonate with a negative FST, the quantitative assay would be the more sensitive test, and the PCR would be confirmatory. ${ }^{83}$ The FST (Trinity Biotech, Wicklow, Ireland) and the CareStart Rapid Diagnostic Test (AccessBio, Somerset, New Jersey) are the two most utilized qualitative tests. ${ }^{83}$

\section{Confirmatory Testing for G6PD Deficiency}

The gold standard confirmatory test for G6PD deficiency is a molecular DNA analysis performed by the PCR method. ${ }^{1,34}$ Genetic testing is the definitive diagnostic tool and can detect heterozygotes with moderate G6PD activity ${ }^{1,34,83}$ Polymerase chain reaction methods are utilized in detecting region-specific alleles; however, alleles from other regions would not be detected with this targeted PCR test. ${ }^{84,85}$ Disadvantages of PCR testing include its high cost and longer time to receive results. ${ }^{1,11}$

Providers could use expedited newborn metabolic screening results when there is suspicion of G6PD deficiency; however, in the United States, only Pennsylvania and Washington DC, screen for G6PD deficiency. ${ }^{11,86}$ Pediatric clinicians need to appreciate the significant risk and manifestations of G6PD deficiency and either expedite the newborn metabolic screen or order a quantitative G6PD assay before discharge in a suspected G6PD-deficient neonate. ${ }^{11,86}$ Most state newborn screening programs are based in the Department of Health and contact information is readily available on each state's website. Providers can communicate with the Department of Health directly, request test results, and request recommendations for follow-up. ${ }^{86}$

Female infants are often overlooked by clinicians because of G6PD deficiency's more commonly recognized X-linked heritability; however, females can also be affected.$^{53}$ Clinicians must recognize that enzyme activity among females may be increased compared to males but still abnormally low. Females often exhibit a $1: 1$ ratio of normal-to-abnormal G6PD enzyme activity. Males commonly present with a more obvious $60-100$ percent reduction in enzyme activity. ${ }^{1,2,5}$ To reduce the risk for false-negative results and missed diagnoses, females should undergo combined enzyme activity testing and molecular screening for G6PD deficiency. ${ }^{13}$ 


\section{LIFESPAN IMPLICATIONS OF G6PD DEFICIENCY}

Long-term implications of G6PD deficiency include acute and chronic hemolytic anemia. ${ }^{39}$ Exposure to oxidative stressors, such as fava beans, naphthalene (moth balls), umbilical triple dye, henna, and certain drugs, could lead to an acute hemolytic reaction and should be avoided (Table 7). ${ }^{1,51,87,88}$ Chronic nonspherocytic hemolytic anemia can occur in a small percentage of G6PD-deficient individuals and typically requires an RBC transfusion when the patient is symptomatic. ${ }^{6,13,39}$ Chronic reticulocytosis occurs and a splenectomy, though rare, may be beneficial to these individuals. ${ }^{6,39,89}$

The long-term consequences associated with undiagnosed and untreated G6PD deficiency are related to severe hyperbilirubinemia, the development of kernicterus, and lifelong devastating neurologic effects. Neurotoxicity as a result of severe hyperbilirubinemia is a disastrous and mostly avoidable disorder, making universal screening a priority. ${ }^{3}$ The lifespan consequences of neurotoxicity involve negative impacts on family well-being, potential physical and emotional suffering of the affected patient, and increased medical costs. ${ }^{34}$

\section{NEWBORN SCREENING FOR G6PD DEFICIENCY}

In 1989 the WHO advised screening newborns for G6PD deficiency in regions with an incidence of three to five percent in males. ${ }^{7,44}$ The goals of the WHO screening recommendations are to recognize infants at high risk for hyperbilirubinemia and to procure treatment to prevent adverse neurotoxic outcomes ${ }^{87}$ Debates are ongoing regarding universal screening in areas with less than the WHO-recommended criteria. ${ }^{15}$ Despite the WHO recommendations, global screening has not been implemented and cases of bilirubin-induced neurotoxicity are still reported. ${ }^{2,10,32,52,90}$ Countries that have implemented G6PD deficiency programs with or without a combined parental education program have demonstrated significantly decreased rates of bilirubin neurotoxicity and kernicterus. ${ }^{10,34,87}$ Table 8 contains a list of countries that have instituted newborn universal screening programs for G6PD deficiency.

TABLE 7 Medications to Avoid in G6PD Deficiency ${ }^{1,8}$

\begin{tabular}{ll}
\hline Medications & Usage \\
\hline Dapsone & Sulfone antibiotic \\
\hline Methylene blue & Methemoglobinemia treatment \\
\hline Nitrofurantoin & Antibacterial \\
\hline Phenazopyridine & Urinary analgesic for simple urinary tract infections \\
\hline Primaquine & Antimalarial \\
\hline Rasburicase & $\begin{array}{c}\text { Hyperuricemia because of tumor lysis syndrome } \\
\text { during chemotherapy treatment }\end{array}$ \\
\hline Toluidine blue & Oral and thyroid malignancies \\
\hline
\end{tabular}

Abbreviation: G6PD = glucose-6-phosphate dehydrogenase.
TABLE 8 Countries with Mandatory Newborn G6PD Deficiency Screening Programs ${ }^{10,34,87}$

\begin{tabular}{c}
\hline Countries \\
\hline Hong Kong \\
\hline Singapore \\
Taiwan \\
Philippines \\
Malaysia \\
Vietnam \\
Thailand \\
Cyprus \\
Greece \\
Italy \\
Germany \\
Saudi Arabia \\
Turkey \\
Lebanon \\
\hline
\end{tabular}

Abbreviation: G6PD = glucose-6-phosphate dehydrogenase.

In the United States the metabolic newborn screen tests for the five most frequently occurring gene variants in this country, encompassing approximately 90 percent of those found in Americans with G6PD deficiency. ${ }^{10,91}$ Routine screening is not performed in the United States and is only recommended by the $\mathrm{AAP}^{42}$ for jaundiced infants undergoing phototherapy treatment who have risk factors of family history or ethnicity, and for neonates who have phototherapy-resistant hyperbilirubinemia. ${ }^{11}$ Glucose-6-phosphate dehydrogenase deficiency screening remains an ongoing discussion in the United States; many pediatricians are in favor of a nationwide screening program. ${ }^{11,12,15,42,92}$

\section{Benefits of Mandated G6PD Screening During the Birth Hospitalization}

The benefits of early G6PD deficiency screening during the birth hospitalization include the identification of affected infants to prevent neurotoxic disability or a decrease in the severity of neurotoxic disability, or the provision of life-rescuing treatment. ${ }^{47,83,87,93}$ Presently, some newborns are discharged home as early as 24 hours of age, but the majority stay in the hospital for 48 hours following a vaginal birth and three to four days for cesarean section births..$^{40,70}$ Therefore, rising bilirubin levels, which typically peak on day of life four or five can be missed. ${ }^{40}$ Glucose-6-phosphate dehydrogenase-deficient newborns can have TsB levels within normal limits at discharge but develop severe hyperbilirubinemia within hours during an acute hemolytic event once they are home. ${ }^{11,40}$ The TsB level cannot be precisely detected by visualization alone, which is often how parents evaluate the degree of hyperbilirubinemia. ${ }^{40,87}$

The United States is considered low risk for G6PD deficiency according to the WHO recommendations; however, 
there are communities that are at an increased risk and should be appraised for G6PD deficiency. ${ }^{12}$ African American infants, highest at risk in the United States for inheriting G6PD deficiency, manifest with lower peak TsB levels than Caucasian infants, making diagnosis of severe hyperbilirubinemia a challenge. ${ }^{3}$ Additionally, African American infants are at a greater likelihood of developing kernicterus after discharge from the birth hospitalization- 25 percent of kernicterus cases in the United States have occurred in African American infants. ${ }^{3,59}$ It is hypothesized that G6PD-deficient infants develop bilirubin-induced neurotoxicity at lower TsB levels than their nonaffected counterparts. ${ }^{3}$ Infants of East Asian descent are also at an increased risk, and, in contrast with African American and Caucasian infants, manifest with significantly higher TsB levels. ${ }^{40}$ Targeted programs for G6PD deficiency screening have been implemented in areas that serve increased numbers of high-risk neonates, such as African Americans, yet these programs will not identify all cases of the deficiency. ${ }^{7,12}$ Universal screening would be advantageous to additionally recognize affected infants with a diverse heritage because of intermarriage. ${ }^{11}$

Establishing and implementing a G6PD deficiency screening program or mechanism utilized by nurses could identify infants at high risk for developing severe hyperbilirubinemia in the birth hospitalization. Identified high-risk infants could then be closely monitored for hyperbilirubinemia and followed after discharge as necessary. Advantages include affordability, more timely screening as compared to the newborn metabolic screen, and ease in performance. Several studies have demonstrated the cost-effectiveness of a G6PD deficiency screening program, with significantly lower costs of screening in contrast to the substantial costs of treating G6PD-deficient infants with neurotoxic consequences. ${ }^{34,94}$ Overall positive effects would be enhanced society health and well-being. The emotional suffering of the parents and the physical and emotional suffering of affected children could be prevented.

\section{Barriers to Mandated G6PD Screening During the Birth Hospitalization}

Several barriers to mandated G6PD deficiency screening during the birth hospitalization have been identified. The fiscal cost of G6PD deficiency testing remains one of the most significant barriers (Table 9). ${ }^{10,83}$ The barrier of organizational restraints includes the addition of a centralized laboratory, highly trained laboratory technicians, and turnaround time for metabolic testing results, which could be considerably past the birth hospitalization at approximately ten days to one month. ${ }^{1,11}$ Furthermore, there exists a perceived paucity of superior-level evidence regarding neurotoxic consequences of extreme hyperbilirubinemia caused by G6PD deficiency. ${ }^{2,10,32,90}$ For example, G6PD deficiency is not included in the U.S.-mandated metabolic newborn screen because of the statement made by the American College of Medical Genetics that G6PD mutations in the United States and their relationship with kernicterus is not clearly defined.
TABLE 9 Financial Cost of G6PD Deficiency Testing ${ }^{1}$

\begin{tabular}{|c|c|}
\hline Test & Financial Cost \\
\hline Molecular analysis & $\$ 1,500$ \\
\hline BinaxNOW* G6PD Test & $\$ 15$ \\
\hline Fluorescent spot test & $\$ 10$ \\
\hline Spectrophotometric analysis & $\$ 8$ \\
\hline
\end{tabular}

Abbreviation: G6PD = glucose-6-phosphate dehydrogenase.

*BinaxNOW G6PD test (Abbott, Abbott Park, Illinois)

However, the recommendations were from 2004, and 15 years later the devastating consequences of G6PD deficiency are still reported. ${ }^{15,95}$

\section{CONCLUSION}

Globally, G6PD deficiency is the most common enzymopathy. Oxidative damage to the erythrocyte results from a deficiency of the G6PD enzyme and can lead to severe hyperbilirubinemia. Neurotoxic consequences can result from G6PD deficiency-induced severe hyperbilirubinemia if not promptly identified and treated. Cases of ABE, BIND, and kernicterus resulting from G6PD deficiency-induced extreme hyperbilirubinemia are still being reported. There is evidence that bilirubin-induced neurotoxicity can be prevented by neonatal G6PD deficiency screening programs. However, no universally mandated metabolic screening or clinical risk assessment tool for G6PD deficiency currently exists in the United States. Glucose-6-phosphate dehydrogenase deficiency screening inclusive of areas that are not considered high-risk, such as the United States, could assist in the identification of infants at a greater threat of developing extreme hyperbilirubinemia-induced neurotoxicity. Targeted screening for high-risk neonates may lead to legal and ethical issues as some G6PD-deficient infants could be missed. Therefore, a cost-effective, time-efficient, and universally mandated G6PD deficiency screening tool utilized during the birth hospitalization and increased provider awareness of this enzymopathy could make kernicterus a "never event."

\section{REFERENCES}

1. Belfield KD, Tichy EM. Review and drug therapy implications of glucose-6-phosphate dehydrogenase deficiency. Am J Health-Syst Pharm. 2018;75(3):97-104. https://doi.org/10.2146/ajhpl60961

2. Cappellini M, Fiorelli G. Glucose-6-phosphate dehydrogenase deficiency. Lancet. 2008;371(9606):64-74. https://doi.org/10.1016/ S0140-6736(08)60073-2

3. Cunningham A, Hwang S, Mochly-Rosen D. Glucose-6-phosphate dehydrogenase deficiency and the need for a novel treatment to prevent kernicterus. Clin Perinatol. 2016;43(2):341-354. https:// doi.org/10.1016/j.clp.2016.01.010

4. Luzzato L, Nannelli C, Notaro R. Glucose-6-phosphate dehydrogenase deficiency. Hematol/Oncol Clin North Am. 2016;30(2):373-393. https://doi.org/10.1016/j.hoc.2015.11.006

5. Mason P, Bautista J, Gilsanz F. G6PD deficiency: The genotypephenotype association. Blood Rev. 2007;21(5):267-283. https:// doi.org/10.1016/j.blre.2007.05.002 
6. Ho L, John R. Understanding and managing glucose-6-phosphate dehydrogenase deficiency. J Nurse Pract. 2015;11(4):443-450. https:// doi.org/10.1016/j.nurpra.2015.01.007

7. Lam R, Li H, Nock M. Assessment of G6PD screening program in premature infants in a NICU. J Perinatol. 2015;35(12):1027-1029. https://doi.org/10.1038/jp.2015.129

8. Watchko JF. Refractory causes of kernicterus in developed countries: Can we eradicate G6PD deficiency triggered and low-bilirubin kernicterus? Curr Pediatr Rev. 2017;13(3):159-168. https://doi.org/10.2174/15 73396313666170718144025

9. Arain YH, Bhutani VK. Prevention of kernicterus in south Asia: Role of neonatal G6PD deficiency and its identification. Indian J Pediatr. 2014;81(6):599-601. https://doi.org/10.1007/s12098-014-1410-y

10. Kaplan M, Hammerman C, Bhutani V. Parental education and the WHO neonatal G-6-PD screening program: A quarter century later. J Perinatol. 2015;35(10):779-784. https://doi.org/10.1038/jp.2015.77

11. Watchko J, Kaplan M, Stark A, Stevenson D, Bhutani V. Should we screen newborns for glucose-6-phosphate dehydrogenase deficiency in the United States? J Perinatol. 2013;33(7):499-504. https:// doi.org/10.1038/jp.2013.14

12. Bernardo J, Nock M. Pediatric provider insight into newborn screening for glucose-6-phosphate dehydrogenase deficiency. Clin Pediatr. 2015;54(6):575-578. https://doi.org/10.1177/0009922814557786

13. Haley K. Congenital hemolytic anemia. Med Clin North Am. 2017;101(2):361-374. https://doi.org/10.1016/j.mcna.2016.09.008

14. Jang MA, Kim JY, Lee KO, Kim SH, Koo HH, Kim HJ. A novel de novo mutation in the G6PD gene in a Korean boy with glucose-6phosphate dehydrogenase deficiency: Case report. Ann Clin Lab Sci. 2015;45(4):446-448.

15. Kaplan M, Hammerman C. The need for neonatal glucose-6phosphate dehydrogenase screening: A global perspective. J Perinatol. 2009;29(S1):S46-S52. https://doi.org/10.1038/jp.2008.216

16. Alabdulaali M, Alayed K, Alshaikh A, Almashhadani S. Prevalence of glucose-6-phosphate dehydrogenase deficiency and sickle cell trait among blood donors in Riyadh. Asian J Transfus Sci. 2010;4(1):31-33. https://doi.org/10.4103/0973-6247.59389

17. Al-Arrayed. Campaign to control genetic blood diseases in Bahrain. Community Genet. 2005;8(1):52-55. https://doi.org/10.1159/ 000083340

18. Al-Riyami A, Ebrahim G. Genetic blood disorders survey in the Sultanate of Oman. Journal of Tropical Pediatrics. 2003;49(Suppl. 1):il-i20.

19. Altay C, Gumruk F. Red cell glucose-6-phosphate dehydrogenase deficiency in Turkey. Turk J Hematol. 2008;25(1):1-7.

20. Azma R, Hidayati N, Farisah N, Hamidah N, Ainoon O. G6PD enzyme activity in normal term Malaysian neonates and adults using an OSMMR2000-D kit with $\mathrm{Hb}$ normalization. Se A Sian J Trop Med Public Health. 2010;41(4):982. https://doi.org/10.1097/ 01268031-200941001-00181

21. Bayoumi R, Nur-E-Kamal M, Tadayyon M, et al. Molecular characterization of erythrocyte glucose-6-phosphate dehydrogenase deficiency in Al-Ain District, United Arab Emirates. Hum Hered. 1996;46(3):136-141. https://doi.org/10.1159/000154342

22. Haung S, Xu Y, Liu X, Zhou M, Wu X, Jia Y. Molecular newborn screening of four genetic diseases in Guizhou province of South China. Gene. 2016;591(1):119-122. https://doi.org/10.1016/ j.gene.07.019

23. Hilmi F, Al-Allwi A, Rassam M, Al-Shamma G, Al-Hashimi A. Red cell glucose-6-phosphate dehydrogenase phenotypes in Iraq. East Mediterr Health J. 2002;8(1):42-48.

24. Hussein I, Yamamah G, Saleh G. Glucose-6-phosphate dehydrogenase deficiency and sulfadimidin acetylation phenotypes in Egyptian oases. Biochem Genet. 1992;30(3-4):113-121. https://doi.org/10.1007/ BF02399702
25. Iwai K, Hirono A, Matsuoka $\mathrm{H}$, et al. Distribution of glucose-6phosphate dehydrogenase mutations in southeast Asia. Hum Genet. 2001;108(6):445-449. https://doi.10.1007/s004390100527

26. Kaban R, Wijaya V. Prevalence of glucose-6-phosphate dehydrogenase (G6PD) deficiency in neonates in Bunda women's and children's hospital, Jakarta, Indonesia. Paediatr Indones. 2011;51(1):29-33. https://doi.org/10.14238/pi51.1.2011.29-33

27. Maffi D, Pasquino M, Mandarino L, et al. Glucose-6-phosphate dehydrogenase deficiency in Italian blood donors: Prevalence and molecular defect characterization. Vox Sang. 2014;106(3):227-233. https://doi.org/10.1111/vox.12096

28. Matsuoka H, Nguon C, Kanbe T, et al. Glucose-6-phosphate dehydrogenase (G6PD) mutations in Cambodia: G6PD Viangchan $(871 \mathrm{G}>\mathrm{A})$ is the most common variant in the Cambodian population. J Hum Genet. 2005;50(9):468-472. https://doi.org/10.1007/s10038-005-0279-z

29. Matsuoka H, Thuan T, Van Thien H, et al. Seven different glucose-6phosphate dehydrogenase variants including a new variant distributed in lam dong province in southern Vietnam. Acta Med Okayama. 2007;61(4):213-219.

30. Molou E, Schulpism K, Thodi G, et al. Glucose-6-phosphate dehydrogenase deficiency in Greek newborns: The Mediterranean C653T mutation screening. Scand J Clin Lab Inv. 2014;74(3):259-263. https://doi.org/10.3109/00365513.2013.879733

31. Nuchprayoon I, Sanpavat S, Nuchprayoon S. Glucose-6-phosphate dehydrogenase (G6PD) mutation in Thailand: G6PD Viangchan $(87 \mathrm{lg}>\mathrm{A})$ is the most common deficiency variant in the Thai population. Hum Mutat. 2002;19(2):185. https://doi.org/10.1002/humu.9010

32. Olysanya B, Emokpae A, Zamora T, Slusher T. Addressing the burden of neonatal hyperbilirubinaemia in countries with significant glucose-6-phosphate dehydrogenase deficiency. Acta Paediatr. 2014;103(11):1102-1109. https://doi.org/1111/apa.12735

33. Quinio M, Torres M. Uticaria pigmentosa in a 6-month old Filipino male with G6PD deficiency. J Am Acad Dermatol. 2016;74(5):AB219AB219. https://doi.org/10.1016/j.jaad.2016.02.862

34. Sirdah MM, Al-Kahlout MS, Reading NS. National G6PD neonatal screening program in Gaza strip of Palestine: Rationale, challenges and recommendations. Clin Genet. 2016;90(3):191-198. https:// doi.10.1111/cge.12786

35. Steensma DP, Hoyer JD, Fairbanks VF. Hereditary red blood cell disorders in middle eastern patients. Mayo Clin Proc. 2001;76(3):285293. https://doi.org/10.4065/76.3.285

36. Rai V, Kumar P. Epidemiological study of glucose-6-phosphate dehydrogenase deficiency in scheduled caste population of India. J Anthropol. 2012;2012:1-5. https://doi.org/10.1155/2012/ 984180

37. Riskin A, Cohen K, Kugelman A, Abend-Weinger M, Hemo M, Bader D. Influence of changes in the evaluation of neonatal jaundice. Am JPerinatol. 2014;31(3):203-208. https://doi.org/10.1055/s-0033-1343772

38. Usanga E, Ameen R. Glucose-6-phosphate dehydrogenase deficiency in Kuwait, Syria, Egypt, Iran, Jordan, and Lebanon. Hum Hered. 2000;50(3):158-161. https://doi.org/10.1159/000022906

39. Grace R, Glader B. Red blood cell enzyme disorders. Pediatr Clin North Am. 2018;65(3):579-595. https://doi.org/10.1016/ j.pcl.2018.02.005

40. Maisels MJ. Managing the jaundiced newborn: A persistent challenge. Can Med Assoc J. 2015;187(5):335-343. https://doi.org/10.1503/ cmaj. 122117

41. National Quality Forum. Serious Reportable Events in Healthcare: A Consensus Report. Washington, DC: National Quality Forum; 2002.

42. American Academy of Pediatrics; Subcommittee on Hyperbilirubinemia. Management of hyperbilirubinemia in the newborn infant 35 or more weeks of gestation. Pediatrics. 2004;114(1):297-316. https:// doi.org/10.1542/peds.114.1.297 
43. Maisels MJ, Bhutani VK, Bogen D, Newman TB, Stark AR, Watchko JF. Hyperbilirubinemia in the newborn infant $>$ or $=35$ weeks' gestation: An update in clarifications. Pediatrics. 2009;124(4):1193-1198. https:// doi.org/10.1542/peds.2009-0329

44. World Health Organization Working Group. Glucose-6-phosphate dehydrogenase deficiency. B World Health Organ. 1989;67(6):601-611.

45. Bhutani V, Zipursky A, Blencowe H, et al. Neonatal hyperbilirubinemia and rhesus disease of the newborn: Incidence and impairment estimates for 2010 at regional and global levels. Pediatr Res. 2013;74(Suppl. 1) (S1):86-100. https://doi.1038/pr.2013.208

46. Nkhoma E, Poole C, Vannappagari V, Hall S, Beutler E. The global prevalence of glucose-6-phosphate dehydrogenase deficiency: Asystematic review and meta-analysis. Blood Cells, Mol Dis. 2009;42(3):267-278. https://doi.org/10.1016/j.bcmd.2008.1

47. Howson C, Cedergren B, Giugliani R, et al. Universal newborn screening: A roadmap for action. Mol Genet Metab. 2018;124(3):177183. https://doi.org/10.1016/j.mgmg.2018.04.009

48. Monzon CM, Fairbanks VF, Burget EO, Sutherland SC. Hematologic genetic disorders among southeast Asian refugees. Am J Hematol. 1985;19(1):27-36. https://doi.org/10.1002/ajh.2830190105

49. United States Census Bureau. QuickFacts United States. Accessed July 1 , 2020. https://www.census.gov/quickfacts/fact/table/US/PST045217

50. Murray CK, Chinevere TD, Grant E, Johnson GA, Duelm F, Hospenthal DR. Prevalence of glucose-6-phosphate dehydrogenase deficiency in the U.S. army personnel. Mil Med. 2006;171(9):905-907. https://doi. org/10.7205/milmed.171.9.905

51. La Vielle S, Lefebvre D, Khalid A, Deca M, Godefroy S. Dietary restrictions for people with glucose-6-phosphate dehydrogenase deficiency. Nutr Rev. 2019;77(2):96-106. https://doi.org/10.1093/ nutrit/nuy053

52. Beutler E. G6PD deficiency. Blood. 1994;84(11):3613-3636. https:// doi.org/10.1182/blood.V84.11.3613.bloodjournal84113613

53. Albayrak C, Albayrak D. Red cell glucose-6-phosphate dehydrogenase deficiency in the northern region of Turkey: Is G6PD deficiency exclusively a male disease? Pediatr Hematol Oncol. 2015;32(2):85-91. https://doi.org/10.3109/08880018.2014.940074

54. Luzzato L, Seneca E. G6PD deficiency: A classic example of pharmacogenetics with on-going clinical implications. Br J Haematol. 2014;164(4):469-480. https://doi.org/10.1111/bjh.12665

55. Pamba A, Richardson N, Carter N, et al. Clinical spectrum and severity of hemolytic anemia in glucose-6-phosphate dehydrogenase-deficiency children receiving dapsone. Blood. 2012;120(20):4123-4133. https:// doi.org/10.1182/blood-2012-03-416032

56. Kaplan M, Beutler E, Vreman HJ, et al. Neonatal hyperbilirubinemia in glucose-6-phosphate dehydrogenase-deficient heterozygotes. Pediatrics. 1999;104(1):68-74. https://doi.org/10.1542/peds.104.1.68

57. Riskin A, Gery N, Kugelman A, Hemo M, Spevak I, Bader D. Glucose-6-phosphate dehydrogenase deficiency and borderline deficiency: Association with neonatal hyperbilirubinemia. J Pediatr. 2012;161(2):191-196. https://doi.org/10.1016/j.peds.2012.02.018

58. Verilli F, Kebriaei H, Glielmo L, Corless M, Vecchio CD. Effects of selection and mutation on epidemiology of X-linked genetic diseases. Math Biosci Eng. 2017;14(3):755-775. https://doi.org/10.3934/ mbe. 2017042

59. Watchko JF. Hyperbilirubinemia in African American neonates: Clinical issues. Semin Fetal Neonat Med. 2010;15(3):176-182. https:// doi.org/10.1016/j.sinj.2009.11.001

60. Costa E, Cabeda J, Vieira E, et al. Glucose-6-phosphate dehydrogenase Aveiro: A de novo mutation associated with chronic non-spherocytic hemolytic anemia. Blood. 2000;95(4):1499-1501.

61. Minucci A, Concolino P, Vendittelli F, Giardina B, Zuppi C, Capoluongo E. Glucose-6-phosphate dehydrogenase Buenos Aires: A novel de novo missense mutation associated with severe enzyme deficiency. Clin Biochem. 2008;41(9):742-745. https://doi.org/10.1016/j/ clinbiochem.2007.11.009

62. van Wijk R, Huizinga E, Prins I, et al. Distinct phenotypic expression of two de novo missense mutations affecting the dimer interface of glucose6-phosphate dehydrogenase. Blood Cells, Mol Dis. 2004;32(1):112-117. https://doi.org/10.1016/j.bcmd.2003.10.006

63. Kaplan M, Bromiker R, Hammerman C. Hyperbilirubinemia, hemolysis, and increased bilirubin neurotoxicity. Semin Perinatol. 2014;38(7):429437. https://doi.org/10.1053/j.semperi.2014.08.006

64. Johnson L, Bhutani VK, Karp K, Sivieri EM, Shapiro SM. Clinical report from pilot USA kernicterus registry. J Perinatol. 2009;29(S1):S25-S45. https://doi.org/10.1038/jp.2008.211

65. Bhutani VK, Johnson-Hamerman L. The clinical syndrome of bilirubininduced neurologic dysfunction. Semin Fetal Neonat Med. 2014;20(1):613. https://doi.org/10.1016/j.siny.2014.12.008

66. Moncrief G. Bilirubin in the newborn: Physiology and pathophysiology. Br J Midwifery. 2018;26(6):362-370. https://doi.org/10.12968/ bjom.2018.26.6.362

67. Morioka I, Iwatani S, Koda T, Jijima K, Nakamura H. Disorders of bilirubin binding to albumin and bilirubin-induced neurologic dysfunction. Semin Fetal Neonat Med. 2014;20(1):31-36. https:// doi.org/10.1016/j.siny.2014.11.001

68. Watchko JF. Bilirubin-induced neurotoxicity in the preterm neonate. Clin Perinatol. 2016;43(2):297-311. https://doi.org/10/1016/j/ clp.2016.01.007

69. Gamaleldin R, Iskander I, Seoud I, Aboraya H, Araykin A, Sampson P. Risk factors for neurotoxicity in newborns with severe neonatal hyperbilirubinemia. Pediatrics. 2011;128(4): https://doi.org/10.1542/ peds.2011-0206

70. Wennberg R, Watchko R, Shapiro S. Maternal empowerment-An underutilized strategy to prevent kernicterus? Curr Pediatr Rev. 2017;13(3):210-219. https://doi.org/10.2174/1573396313666170 828112038

71. Bromiker R, Medoff-Cooper B, Flor-Hirsch H, Kaplan M. Influence of hyperbilirubinemia on neonatal sucking. Early Hum Dev. 2016;99:5356. https://doi.org/10.1016/j.earlhumdev.2016.04.008

72. Maisels MJ, Watchko JF, Bhutani VK, Stevenson DK. An approach to the management of hyperbilirubinemia in the preterm infant less than 35 weeks of gestation. J Perinatol. 2012;32(9):660-664. https://doi. org/10.1038/jp.2012.71

73. Bhutani V, Johnson L, Sivieri E. Predictive ability of a predischarge hourspecific serum bilirubin for subsequent significant hyperbilirubinemia in healthy term and near-term newborns. Pediatrics. 1999;103(1):6-14. https://doi.org/10.1542/peds.103.1.6

74. Will A, Henderson C, Jnah A, Newberry D. Hereditary spherocytosis in the neonatal period: A case report. Neonatal Netw. 2017;36(5): 280-288.

75. Christensen R, Nussenzveig R, Yaish H, Henry E, Eggert L, Agarwal A. Causes of hemolysis in neonates with extreme hyperbilirubinemia. $J$ Perinatol. 2014;34(8):616-619. Https://doi.org/10.1038/jp.2014.68

76. Luzzato L. Glucose-6-phosphate dehydrogenase deficiency: From genotype to phenotype. Haematologica. 2006;91(10):1303-1306.

77. Raimbault A, Chapuis N. Plasma cell leukemia revealing a G6PD deficiency. Blood. 2016;128(26):3178. https://doi.org/10.1182/ blood-2016-08-736322

78. Segel GB, Hackney LR. Glucose-6-phosphate dehydrogenase deficiency and related deficiencies. In: Kleigman RM, Nelson WE, eds. Nelson's Textbook of Pediatrics. 19th ed. Philadelphia, PA: Elsevier Saunders; 2009.

79. Nantakomol D, Palasuwan A, Chaowanathikhom M, Soogarun S, Imwong M. Red cell and platelet-derived microparticles are increased 
in G6PD-deficient subjects. Eur J Hematol. 2012;85(5):423-429. https://doi.org/10.1111/ejh.12010

80. Janus J, Moerschel S. Evaluation of anemia in children. Am Fam Physician. 2010;81(12):1462-1471.

81. Karllson M, Dung K, Thi T, et al. Lactate dehydrogenase as an indicator of severe illness in neonatal intensive care patients: A longitudinal cohort study. Acta Paediatr. 2012;101(12):1225-1231. https://doi. org/10.1111/apa.12014

82. Watchko JF. Common hematologic problems in the newborn nursery. Pediatr Clin North Am. 2015;62(2):509-524. https:// doi.org/10.1016/j.pcl.2014.11.011

83. Bhutani V, Kaplan M, Glader B, Cotten M, Kleinert J, Pamela V. Pointof-care quantitative measure of glucose-6-phosphate dehydrogenase enzyme deficiency. Pediatrics. 2015;136(5):el268-e1275. https:// doi.org/10.1542/peds.2015-2122

84. Hsu J, Fink D, Langer E, et al. PCR-based allelic discrimination for glucose-6-phosphate dehydrogenase (G6PD) deficiency in Ugandan umbilical cord blood. Pediatr Hematol-Oncol. 2014;31(1):68-75. https://doi.org/10.3109/08880018.2013.860649

85. Wang F, Boo N, Ainoon O, Wong M. Comparison of detection of glucose-6-phosphate dehydrogenase deficiency using fluorescent spot test, enzyme assay and molecular method for prediction of severe neonatal hyperbilirubinaemia. Singap Med J. 2009;50(1):62-67.

86. Mew N, Viall S, Kirmse B, Chapman K. Deconstructing black swans: An introductory approach to inherited metabolic disorders in the neonate. Clin Issues Neonatal Care. 2015;15(4):241-247. https:// doi.org/10.1097/ANC.0000000000000206

87. Kaplan M, Hammerman C, Bhutani V. The preterm infant: A high-risk situation for neonatal hyperbilirubinemia due to glucose-6-phosphate dehydrogenase deficiency. Clin Perinatol. 2016;43(2):325.

88. Youngster L, Arcavi L, Schechmaster R, et al. Medications and glucose-6-phosphate dehydrogenase deficiency: An evidencebased review. Drug Safety. 2010;33(9):713-726. https://doi.org/ $10.2165 / 11536520-000000000-00000$

89. Hamilton JW, Jones FG, McMillin MF. Glucose-6-phosphate dehydrogenase Guadalajara-A case of chronic non-spherocytic haemolytic anaemia responding to splenectomy and the role of splenectomy in this disorder. Hematology. 2004;9(4):307-309.

90. Kaplan M, Hammerman C. Glucose-6-phosphate dehydrogenase deficiency and severe neonatal hyperbilirubinemia: A complexity of interactions between genes and environment. Semin Fetal Neonatal Med. 2010;15(3):148-156. https://doi.org/10.1016/j.siny.2009.10.007

91. Lin Z, Fontaine J, Freer D, Naylor E. Alternative DNA-based newborn screening for glucose-6-phosphate dehydrogenase deficiency. Mol Genet Metab. 2005;86(1):212-219. https://doi.org/10.1016/j.ymgme.2005. 05.008

92. Slusher T, Zipursky A, Bhutani V. A global need for affordable neonatal jaundice technologies. Semin Perinatol. 2011;35(3):185-191. https:// doi.org/10.1053/j.semperi.2011.02.014

93. March of Dimes, World Health Organization. Management of Birth Defects and Haemoglobin Disorders: Report of a Joint World Health Organization-March of Dimes Meeting. Geneva, Switzerland: Author; 2006.

94. Darbandi B, Noghbaei M, Mehrabian F, Jafroodi M. Medical expenses of patients with Favism admitted to 17th shahrivar hospital compared to
G6PD enzyme screening cost, in north of Iran. Iran J Pediatr Hematol Oncol. 2014;4(2):53-56.

95. Koopmans J, Hiraki S, Ross L. Attitudes and beliefs of pediatricians and genetic counselors regarding testing and screening for CF and G6PD: Implications for policy. Am J Med Genet Part A. 2006;140A(21):23052311. https://doi.org/10.1002/ajmg.a.31463

\section{About the Authors}

Julie Jensen DelFavero, RN, BSN, is currently practicing in Cleveland Clinic Children's Hospital in Cleveland, Ohio, and has been a NICU nurse for 24 years.

Amy J. Jnah, DNP, APRN, NNP-BC, currently practices as an APRN and is the Director of the NNP program at East Carolina University in Greenville, North Carolina.

Desi Newberry, DNP, APRN, NNP-BC, currently practices as an APRN and is a Clinical Associate Professor at East Carolina University College of Nursing in Greenville, North Carolina.

For further information, please contact:

Julie Jensen DelFavero, RN, BSN

East Carolina University

E 5th Street

Greenville, NC 27858

E-mail: jensendelfaveroj18@students.ecu.edu

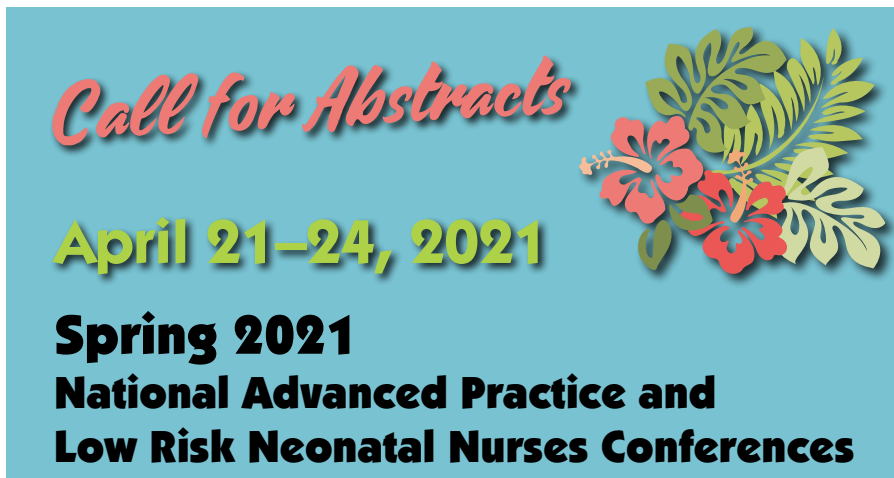

Hilton Hawaiian Village

Waikiki Beach, Honolulu, Hawaii
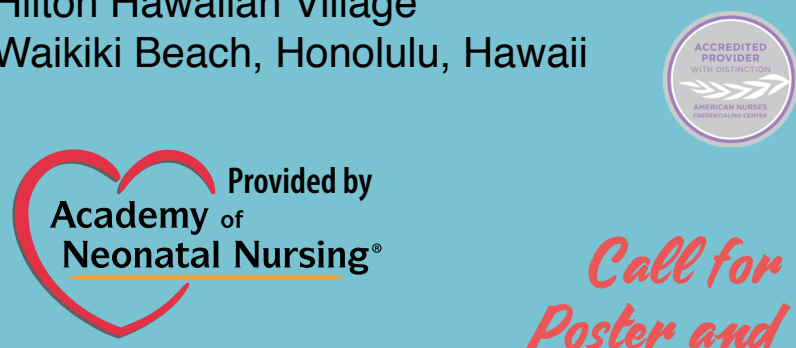

Academy of

Neonatal Nursing ${ }^{\circ}$

Neonatal

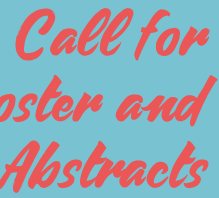

Poclinem Mlostreacts

Submission Deadline January 31, 2021 